\title{
Hysterothecia production of Lophodermium species (Ascomycetes) in relation to industrial air pollution
}

\author{
KARI HELIÖVAARA, RAUNO VÄISÄNEN and ANTTI UOTILA
}

\begin{abstract}
HELIÖVAARA, K., VÄISÄNEN, R. \& UOTILA, A. 1989: Hysterothecia production of Lophodermium species (Ascomycetes) in relation to industrial air pollution. Karstenia 29:29-36.

The abundance of Lophodermium species on Pinus sylvestris was studied in the surroundings of the industrial town Harjavalta in southwestern Finland. The hysterothecia production of these ascomycete species in litter needles was related to the distance from the factory complex producing copper, nickel, sulphuric acid and fertilizers, and to the chemical composition of living needles.

All the species suffered from a high level of industrial air pollution, being almost totally absent within $800 \mathrm{~m}$ of the factory complex. In most cases, the numbers of hysterothecia per needle correlated positively with the distance from the factory complex. Depending on the species, $5-48 \%$ of the variation of hysterothecia production could be explained by the concentrations of elements in living pine needles, the level of heavy metals playing a major role.
\end{abstract}

Kari Heliövaara, The Finnish Forest Research Institute, PL 18, SF-01301 Vantaa, Finland

Rauno Väisänen, Department of Entomology, Zoological Museum and Department of Zoology, University of Helsinki, P. Rautatiekatu 13, SF-00100 Helsinki, Finland Antti Uotila, National Board of Forestry, PL 233, SF-00121 Helsinki, Finland

\section{Introduction}

In forests suffering from chronic air pollution, changes may occur in the species composition of the saprophytic fungi on the foliage. Pollution-induced stress weakens forest trees and makes them more susceptible to attack by fungi and insects. There are many observations of cases in which industrial emissions have increased the abundance of fungal species and enhanced their pathogenicity (Darley \& Middleton 1966, Costonis \& Sinclair 1967, Chiba \& Tanaka 1968, Grzywacz 1973, Huttunen 1978, Lechowicz 1987). Several non-lichenized fungal species have also been reported to decrease or disappear in forests in industrial regions (Grywacz \& Ważny 1973, Heagle 1973, Nash 1973, Rühling et al. 1984, Winterhoff \& Krieglsteiner 1984).

Recent research has shown that the needles of pines in Europe are inhabited by at least four species of the ascomycete genus Lophodermium, namely $L$. pinastri (Schrad. ex Hook.) Chev., L. conigenum
Hilitzer, L. seditiosum Minter, Staley \& Millar and $L$. pini-excelsae Ahmad (Minter et al. 1978, Minter 1981a, b). In earlier studies, all these species have been included in $L$. pinastri. Only $L$. seditiosum has proved to be a serious pathogen (Kurkela 1979, Diwani \& Millar 1987). Decrease of $L$. pinastri has been documented in pine stands strongly affected by air pollutants (Kowalski \& Budnik 1976, Kowalski 1981). Near industrial areas, however, low levels of $\mathrm{SO}_{2}$ and its derivatives have been shown to stimulate the occurrence of $L$. pinastri on pine needles (Grzywacz \& Wàzny 1973). L. seditiosum has also shown a tendency to decrease in abundance on pine needles with increasing concentration of air pollutants (Kowalski 1981).

When the direct effects of air pollutants are considered, it is important to know both the concentrations and composition of the pollutants. The purpose of this study was to relate emissions of industrial air pollutants to the hysterothecium production and 
abundance of Lophodermium species by examining needles of Scots pine (Pinus sylvestris L.) in litter in the field. Chemical needle analyses (Heliövaara \& Väisänen 1989) were used to quantify the air pollutants and their effects on pines.

\section{Material and methods}

\section{Study area and sampling}

The field work was carried out around the industrial town of Harjavalta in southwestern Finland (Finnish uniform grid $27^{\circ} \mathrm{E} 680: 24$ ) in September 1987. The town contains two factories, one of which produces copper and nickel and the other sulphuric acid and fertilizers. The main pollutants emitted are sulphuric oxides and heavy metals. For more detailed information on the study area, and the pollutants and their effects, see Laaksovirta and Silvola (1975), Hynninen (1986), Kuokkanen (1986), Sippola and Erviö (1986).

The samples were taken along two 9-km-long transects directed S and SW from the factory complex. On both transects were nine sample plots, located at approximately logarithmic distances (Fig. 1). These plots were selected to represent young pine stands which were as similar as possible. Litter needles were sampled under 10 pines in every plot. The 180 samples taken yielded 6133 needles (Table 1). In addition, the most abundant vascular plant species at every plot were recorded.

\section{Needle analyses}

Living needles from the study trees were analysed for 17 elements or substances, using LECO CHN-600
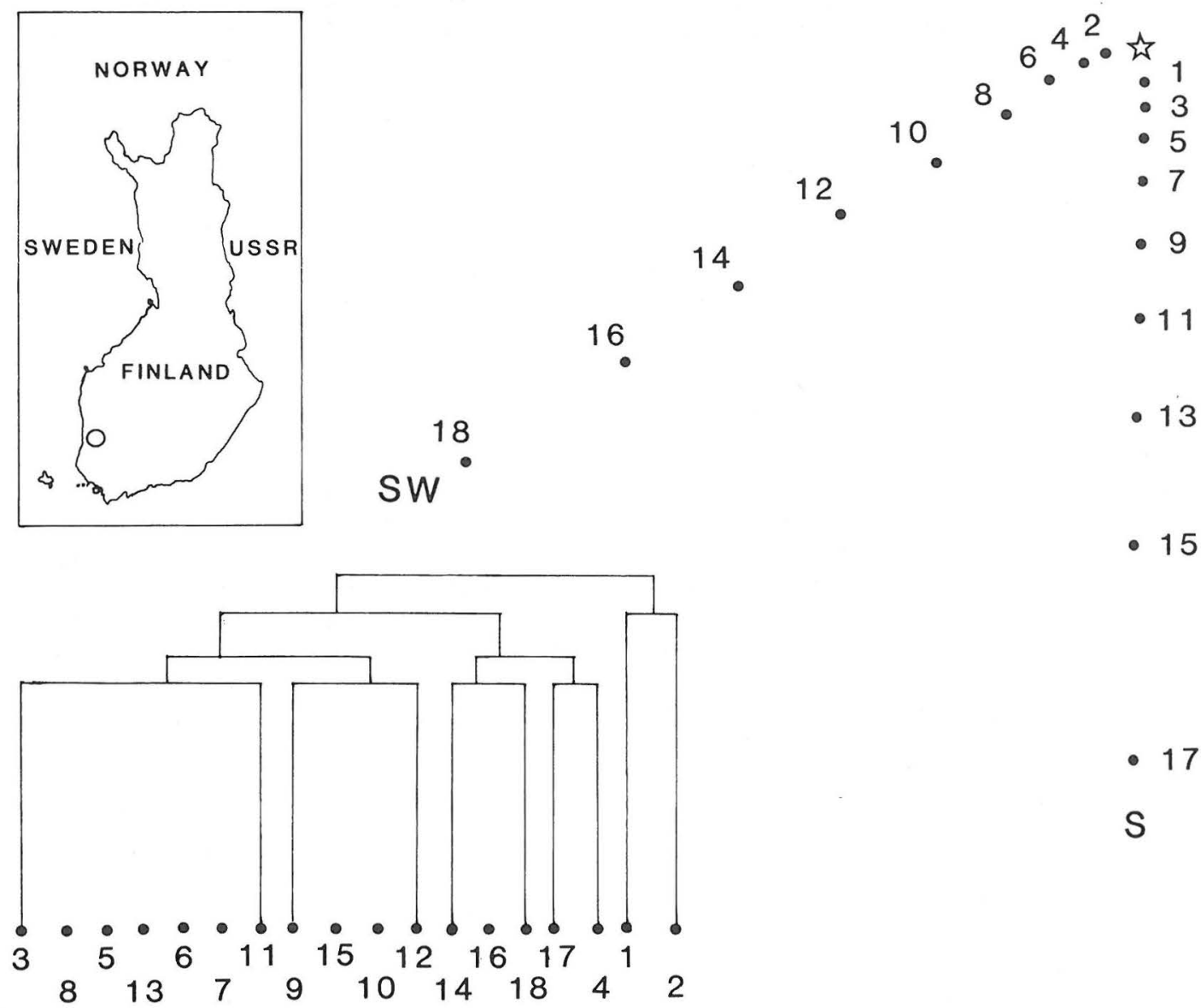

- 15

S

Fig. 1. A schematic map showing the location of the sample plots and the dendrogram of a two-way indicator species analysis (TWINSPAN). Numbered dots represent sample plots in order of increasing distance from the emission source (star). 
Table 1. Comparison of closely related Lophodermium species.

\begin{tabular}{llllc}
\hline Species & zones & $\begin{array}{c}\text { Colour of } \\
\text { lips }\end{array}$ & ascocarp & $\begin{array}{c}\text { Length of } \\
\text { ascocarp, mm }\end{array}$ \\
\hline L. pinastri & black & red-brown & $>1 / 2$ black in centre & $0.7-1.2$ \\
L. sp. & black & grey & $>1 / 2$ black in centre & $0.3-0.8$ \\
L. seditiosum & (brown) & blue or green & grey & $0.8-1.6$ \\
L. conigenum & (brown) & green & $<1 / 4$ black in centre & $0.9-2.0$ \\
\hline
\end{tabular}

and ICP plasma analysers. The results of the analyses are presented in a separate study (Heliövaara \& Väisänen 1989). The main trends revealed were those of the concentrations of heavy metals $(\mathrm{Cu}, \mathrm{Fe}, \mathrm{Zn})$ and sodium, which followed a linear regression model, decreasing with increasing distance from the factory complex, whereas magnesium and manganese increased. Aluminium, phosphorus, hydrogen and nitrogen did not show any clear pattern as functions of distance from the factory complex.

\section{Identification of Lophodermium species}

Dry or wet needle fascicles were examined with a stereomicroscope. The main characters used to distinguish between the species were as follows: 1) black or brown zones in the needles, 2) the colour on the lips of the hysterothecium, 3 ) the size of the hysterothecium, and 4) the black colour around the lips of the dry hysterothecium (Table 1).

The taxonomical status of " $L$. sp." is unclear. It closely resembles $L$. pini-excelsae, which can be distinguished from the very near species $L$. staleyi Minter by the thicker basal wall in its hysterothecium and shorter conidia (Minter 1981a). Lophodermium piniexcelsae has not been reported from northern Europe. It was described from West Pakistan and has since then been reported from several Pinus species from Ireland, Great Britain, Belgium, India, Japan and Canada. $L$. pini-excelsae has been considered a native of the north-western Himalayas on five-needle pines and an introduction in Europe and North America. In England it has been observed fruiting on senescent needles in the litter of Pinus pumila, but there is no information on its ecology in the regions where it is said to be indigenous (Minter 1981a, Minter \& Millar 1984). However, the Finnish material does not necessarily belong to $L$. pini-excelsae (Dr. D.W. Minter, pers. comm.). L. sp. may also represent an undescribed species or a highly differentiated variant of $L$. pinastri. In our samples $L$. sp. had often, but not always, black zones in the needles. The conidiomata were sometimes of the same colour as the needle, only the ostiole being visible, but more often there was some black colour on the conidiomata. Representative specimens are deposited in the Department of Forest Protection (A. Uotila), the Finnish Forest Research Institute.

All ripened hysterothecia were counted. Identification was not absolutely sure in all cases, but on the basis of the needle zones two groups can be separated reliably. $L$. pinastri and $L$. sp. have black zones while in $L$. seditiosum and $L$. conigenum the zones are brown, if present. When these two groups occurred in the same needle there was a wide brown zone close to a narrow black zone in the border between the two groups. $L$. pinastri and $L$. sp. and sometimes also grew in the same needle, causing two black zones next to each other.

\section{Statistical analyses}

The average number of hysterothecia per needle fascicle was calculated for each sample in every sample plot. This was done separately for every Lophodermium species. Differences in the abundance of hysterothecia were tested with the Kruskal-Wallis test. The abundance of Lophodermium species was related to the distance from the industrial plant by using linear regression analysis. Estimates of the parameters of a multiple linear regression were calculated by entering variables in a stepwise manner from the list of potential predictors, which were obtained from the chemical needle analysis. A two-way indicator species analysis (TWINSPAN) (Gauch 1982, Goldsmith et al. 1986) was applied to classify the sample plots according to their vegetation (Fig. 1).

\section{Results}

\section{Fungal flora}

$L$. pinastri, $L$. conigenum and $L$. seditiosum have often been observed on Scots pine needles in Fin- 
Table 2. Total number of hysterothecia, and number of hysterothecia per needle (mean, standard deviation) on the two transects $(\mathrm{S}, \mathrm{SW})$. Statistically significant differences are given in numbers per needle between sample plots (H, Kruskal-Wallis test, $\mathrm{n}=8)$.

\begin{tabular}{|c|c|c|c|c|c|c|}
\hline \multirow[t]{3}{*}{ Species } & \multicolumn{2}{|c|}{ No. of hysterothecia } & \multicolumn{4}{|c|}{ No. of hysterothecia/needle } \\
\hline & \multirow[t]{2}{*}{$S$} & \multirow[t]{2}{*}{ SW } & \multicolumn{2}{|c|}{$\mathrm{S}$} & \multicolumn{2}{|c|}{ SW } \\
\hline & & & $\overline{\mathrm{x}}$ & $\mathrm{SD}$ & $\bar{x}$ & $\mathrm{SD}$ \\
\hline L. pinastri & 2415 & 2941 & 0.78 & 0.86 & 1.14 & 1.56 \\
\hline L. sp. & 569 & 463 & 0.15 & 0.29 & 0.17 & 0.48 \\
\hline L. conigenum & 141 & 326 & 0.04 & 0.11 & 0.11 & 0.29 \\
\hline L. seditiosum & 103 & 268 & 0.04 & 0.13 & 0.10 & 0.51 \\
\hline Total & 3228 & 3998 & 1.00 & 1.00 & 1.51 & 1.92 \\
\hline
\end{tabular}

land. In all but one of the sample plots in Harjavalta where hysterothecia were recorded, $L$. pinastri was the most abundant species in the needle litter. Of the recorded 7226 hysterothecia, $5356(74.1 \%)$ belonged to this species (Table 2). On average, 0.87 hysterothecia of $L$. pinastri were counted per studied needle. $L$. sp. was the second most abundant taxon, being represented by $1032(14.3 \%)$ hysterothecia. The two other species, $L$. conigenum and $L$. seditiosum, were much less numerous, 467 (6.5\%) and 371 $(5.1 \%)$ hysterothecia being counted, respectively.

Abundance of hysterothecia along the pollutant gradient

The adverse effects of air pollution can be seen in the poorly developed vegetation of the study sites near the pollutant source (Fig. 1). The two-way indicator species analysis suggests that the primary division among the habitats is that between exposed mineral soil sites $(1,2)$ and the others, because the vegetation of the field layer has vanished near the factories. The division is clearly related to the level of air pollution. TWINSPAN further distinguishes the sample plots with a denser vegetation cover and mires $(4,14,16$, $17,18)$ and forest on mineral soil.
In the two sample plots nearest to the factory complex, all the Lophodermium species seemed to be very scarce. Not a single hysterothecia was observed in these plots on the S transect, and on the SW transect, only 22 hysterothecia of $L$. pinastri and 8 of $L$. conigenum were found within $800 \mathrm{~m}$ of the factory complex. The numbers of hysterothecia per needle differed highly significantly statistically between the sample plots in every species (Table 2).

A linear regression model was fitted to the hysterothecia records. The numbers of hysterothecia seemed to correlate positively with the distance from the emission source in all four Lophodermium species (except $L$. sp. on the $\mathrm{S}$ transect), but the correlation was statistically significant only for $L$. pinastri on both transects and for $L$. conigenum on one transect (Table 3, Fig. 2). In the pooled data, the highest numbers of hysterothecia/needle were observed at a distance of 5-6 km from the factory complex on both transects.

\section{Chemical components of pine needles}

The needle concentrations of heavy metals give a measure of the general level of atmospheric pollution in the study area. For example, within $800 \mathrm{~m}$ of the

Table 3. Linear regression models for the dependence of Lophodermium species on distance from the pollutant source $(n=90)$.

\begin{tabular}{|c|c|c|c|c|c|c|}
\hline \multirow[b]{2}{*}{ Species } & \multicolumn{3}{|c|}{$S$ transect } & \multicolumn{3}{|c|}{ SW transect } \\
\hline & Equation & $\mathrm{r}$ & $\mathrm{P}<$ & Equation & $\mathrm{r}$ & $\mathrm{P}<$ \\
\hline L. pinastri & $y=0.178 x+0.21$ & 0.468 & 0.001 & $y=0.355 x-0.15$ & 0.648 & 0.001 \\
\hline L. sp. & $y=-0.009 x+0.18$ & -0.071 & NS & $y=0.014 x+0.12$ & 0.083 & NS \\
\hline L. conigenum & $y=0.007 x+0.02$ & 0.128 & NS & $y=0.034 x+0.02$ & 0.329 & 0.001 \\
\hline L. seditiosum & $y=0.012 x+0.41$ & 0.422 & NS & $y=0.029 x-0.01$ & 0.161 & NS \\
\hline
\end{tabular}


pollutant source, the concentrations of copper, iron and zinc were 55-898, 284-1720, and 48-164 $\mu \mathrm{g} / \mathrm{g}$ dry weight, respectively (for details, see Heliövaara \& Väisänen 1989). Stepwise regression analysis using all variables from the chemical needle analyses was applied for each Lophodermium species along both transects (Table 4) and was found to explain 5$48 \%$ of the variation in hysterothecia numbers along the pollution gradients. The concentration of iron explained $24 \%$ of the occurrence of $L$. pinastri on the $S$ transect. Replacement of iron with another heavy metal $(\mathrm{Cu}, \mathrm{Zn})$ did not greatly decrease the explanatory potential of the model, due to the high intercorrelation of all heavy metals (and $\mathrm{Na}$ ). Iron and hydrogen together accounted for $31 \%$ of the variation of $L$. pinastri on the $\mathrm{S}$ transect. On the other transect, aluminium explained more of the variation of $L$. pinastri than zinc or other heavy metals. Phosphorus and manganese increased the proportion of the variation explained to $48 \%$. In the other Lophodermium species, hysterothecia production did not depend so clearly on the distance from the factory complex, and no clear regressions on the chemical components could be obtained (Table 4).

\section{Discussion}

The scarcity of lichens in polluted areas is well documented (Fenton 1960, Ferry et al. 1973, Anderson 1984). The incidence of some other fungi growing on plant foliage has also been reported to be reduced by atmospheric pollutants, such as sulphur dioxide, in the vicinity of industry (for a review, see Huttunen 1984). For example, the tar spot, Rhytisma acerinum (Pers. ex St. Amans) Fr., has been observed to be absent in areas with a high concentration $\left(>90 \mu \mathrm{g} / \mathrm{m}^{3}\right.$ ) of $\mathrm{SO}_{2}$ (Bevan \& Greenhalgh 1976, Oszako 1985). Even $\mathrm{SO}_{2}$ concentrations of $20-$ $90 \mu \mathrm{g} / \mathrm{m}^{3}$ have been observed to decrease the tar spot disease (Bevan \& Greenhalgh 1976).

The results of the present study show that the four Lophodermium species examined had suffered from the high level of industrial air pollution. This was indicated by the almost total absence of hysterothecia within a distance of $800 \mathrm{~m}$ from the emission source. The tendencies were rather similar in all the studied fungal species, but the adverse effect of air pollution was clearest in the most abundant species, $L$. pinastri. The decrease of the Lophodermium species is probably directly due to the toxicity of the industrial emissions, but indirect effects, such as impoverished vegetation and associated changes in the microclimate may have played an additional role.

Grzywacz and Ważny (1973) reported that the intensity of Lophodermium damage on pine depended on the distance from a pollutant source. In the vicinity of an industrial plant emitting fluorines, dust and about $600 \mathrm{~kg} \mathrm{SO} 2$ per hour, the damage caused by "L. pinastri" (L. seditiosum?) was insignificant, but at a distance of about $1 \mathrm{~km}$ the species had clearly increased. The abundance of the fungus then slightly decreased with increasing distance. They also found that the emissions affected the occurrence of the anamorph and teleomorph of the fungus, the size of the apothecia, and their proper ripening. The proportion of regularly developed apothecia was reduced within $1.5 \mathrm{~km}$ of the factories, and the apothecia were smaller near the pollutant source. The proportion of needles with only pycnidia was highest at a site about $1 \mathrm{~km}$ from the emitter. Costonis and Sinclair (1972) did not find that the susceptibility to invasion by $L$. pinastri differed between healthy and ozone-injured needles of Pinus strobus. Kowalski (1981) observed

Table 4. Elements included in the regression equation in stepwise regression analysis for the two transects (S, $\mathrm{SW})$. All variables having an $\mathrm{F}$ value higher than $4.0(\mathrm{P}<0.01)$ at each step have been included for each species.

\begin{tabular}{|c|c|c|c|c|c|}
\hline Species & $\begin{array}{l}\text { Step } \\
\text { no. }\end{array}$ & Element & $\begin{array}{c}\text { S } \\
\text { Partial } \\
\text { r }\end{array}$ & $\mathrm{F}$ & $\underset{\mathrm{R}}{\text { Multiple }}$ \\
\hline L. pinastri & $\begin{array}{l}1 \\
2 \\
3 \\
4\end{array}$ & $\begin{array}{l}\mathrm{Fe} \\
\mathrm{H}\end{array}$ & $\begin{array}{l}-0.487 \\
-0.309\end{array}$ & $\begin{array}{r}26.78 \\
8.96\end{array}$ & 0.557 \\
\hline L. sp. & $\begin{array}{l}1 \\
2\end{array}$ & $\mathrm{Cu}$ & -0.222 & 4.48 & 0.222 \\
\hline L. conigenum & $\begin{array}{l}1 \\
2\end{array}$ & $\begin{array}{l}\mathrm{Na} \\
\mathrm{N}\end{array}$ & $\begin{array}{r}-0.227 \\
0.291\end{array}$ & $\begin{array}{l}4.68 \\
7.87\end{array}$ & 0.363 \\
\hline L. seditiosum & $\begin{array}{l}1 \\
2 \\
3\end{array}$ & ash w & -0.226 & 4.64 & 0.226 \\
\hline
\end{tabular}




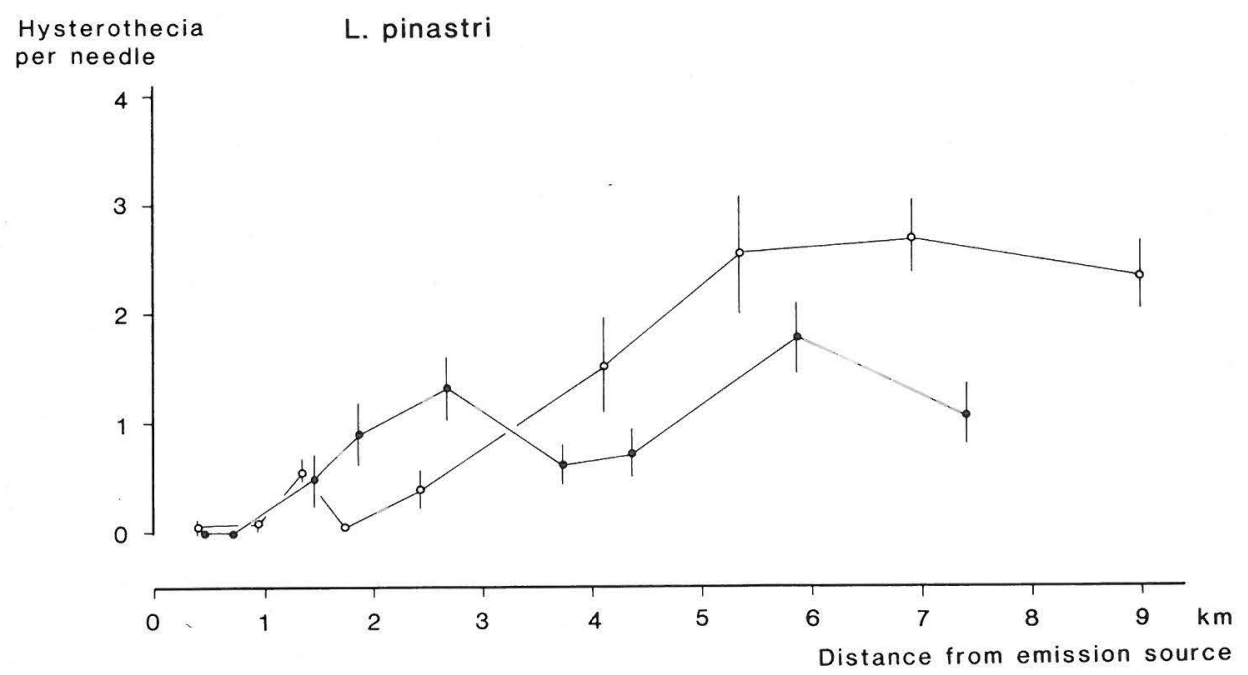

L. $s p$.

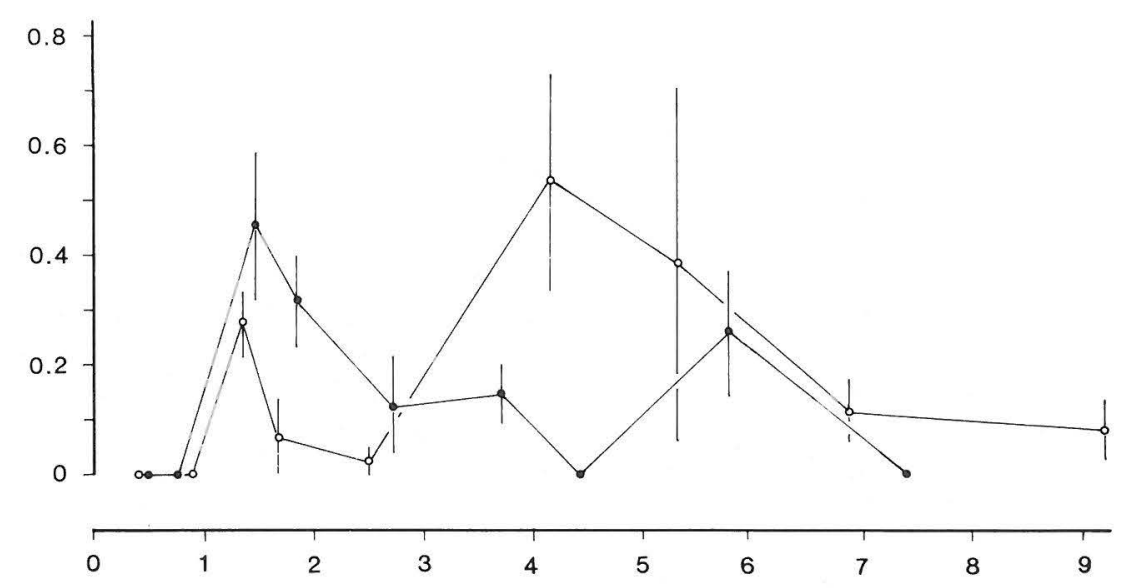

L. seditiosum

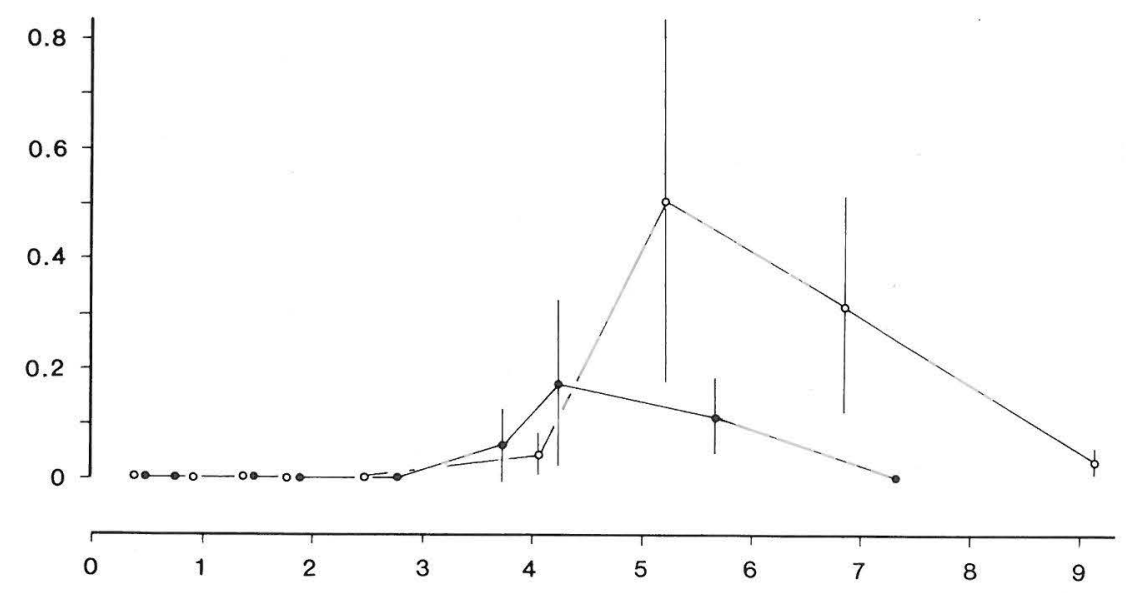

Fig. 2. See the following page. 
L. conigenum

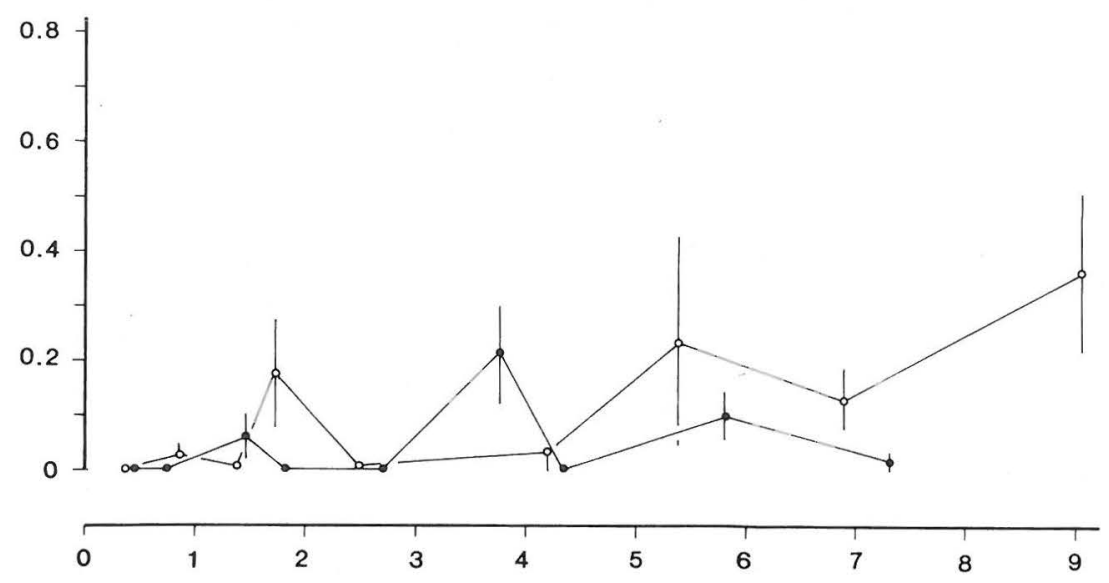

Fig. 2. Hysterothecia production (mean, standard error of mean) of the Lophodermium species along a decreasing pollutant gradient on the two transects (dots: $\mathrm{S}$ transect, circles: SW transect). For linear regression models, see Table 3.

that the amount of $L$. seditiosum mycelium in the needles of Scots pine was lower in polluted than in unpolluted areas. He also found that $L$. pinastri was slightly more abundant on needles collected from pine stands moderately injured by air pollutants than on needles collected from the pollutant-free zone and the zone strongly affected by pollutants. Our results support the conclusion that $L$. pinastri and other Lophodermium species occur in low numbers near an emission source, but they do not indicate whether the fungi benefit from a moderate level of pollution.

Previous studies have shown high concentrations of heavy metals in the study area (Hynninen 1986, Hynninen \& Lodenius 1986). Metal ions are known to have fungicidal properties, and copper and mercury are used as components of fungicidal preparations (Horsfall 1956, Miller \& McCallan 1957, Smith 1977). Thus, the absence of hysterothecia near the factories could be explained by high levels of heavy metals. This explanation has also been suggested for reductions in the fungal biomass in the soil, decreased sporophore production of macrofungi, change the species composition of the soil fungal community (Rühling et al. 1984), reductions in the forest soil microflora (Jordan \& Lechevalier 1975) and decreased invertebrate numbers around pollutant sources (Bengtsson \& Rundgren 1984, Beyer et al. 1985, Heliövaara et al. 1987).

Acknowledgements. We wish to thank Prof. Timo Kurkela and Dr. Lalli Laine for commenting on the manuscript, and Mr. E. Kemppi and Miss Taina Hirvonen for help in sampling and data handling. Of the authors, K.H. and R.V. were responsible for planning the study, analysing the data and writing the text. A.U. assisted in identifying the species and prepared the samples for collections. Financial support from the Finnish Acidification Research Project (HAPRO) is gratefully acknowledged.

\section{References}

Anderson, F.K. 1984: Responses of lichens to atmospheric pollution. - In: Treshow, M. (ed.), Air pollution and plant life, pp. 259-289. - 486 pp. Chichester.

Bengtsson, G. \& Rundgren, S. 1984: Ground-living invertebrates in metal-polluted forest soils. - Ambio 13: 29-33.

Bevan, R.J. \& Greenhalgh, G.N. 1976: Rhytisma acerinum as a biological indicator of pollution. - Envi- ronm. Poll. 10:271-285.

Beyer, W.N., Pattee, O.H., Sileo, L. Hoffman, D.J. \& Mulhern, B.M. 1985: Metal contamination in wildlife living near two zinc smelters. - Environm. Poll. (Ser. A) 38:63-86.

Chiba, O. \& Tanaka, K. 1968: The effect of sulphur dioxide on the development of pine needle blight caused by Rhizosphaera kalkhoffii (L.) Bubak. - J. Jap. Forest. 
Soc. 59:135-139.

Costonis, A.C. \& Sinclair, W.A. 1967: Effects of Lophodermium pinastri and Pullularia pullulans on healthy and ozone-injured needles of Pinus strobus. Phytopathology 57:807.

Darley, E.F. \& Middleton, J.T. 1966: Problems of air pollution in plant pathology. - Ann. Rev. Phytopath. 4:103-118.

Diwani, S.A. \& Millar, C.S. 1987: Pathogeneity of three Lophodermium species on Pinus sylvestris L. Eur. J. For. Path. 17:53-59.

Fenton, A.F. 1960: Lichens as indicators of atmospheric pollution. - Irish Natur. J. 13:153-159.

Ferry, B.W., Baddeley, M.S. \& Hawksworth, D.L. (eds.) 1973: Air pollution and lichens. - 389 pp. London.

Gauch, H.G. Jr. 1982: Multivariate analysis in community ecology. Cambridge studies in ecology. - 298 pp. New York.

Goldsmith, F.B., Harrison, C.M. \& Morton, A.J. 1986: Description and analysis of vegetation. - In: Moore, P.D. \& Chapman, S.B. (eds.), Methods in plant ecology, pp. 437-524. - 589 pp. Boston.

Grzywacz, A. 1973: Sensitivity of Fomes annosus (Fr.) Cooke and Schizophyllum commune Fr. to air pollution with sulphuric dioxide. - Acta Soc. Bot. Poloniae 42: $347-360$.

Grzywacz, A. \& Ważny, J. 1973: The impact of industrial air pollutants on the occurrence of several important pathogenic fungi of forest trees in Poland. - Eur. J. Forest Path. 3:129-141.

Heagle, A.S. 1973: Interactions between air pollutants and plant parasites. - Ann. Rev. Phytopathol. 11:365-388.

Heliövaara, K. \& Väisänen, R. 1989: Quantitative variation in chemical elements of Scots pine needles along a pollutant gradient. - Silva Fenn. (in press).

Heliövaara, K., Väisänen, R., Braunschweiler, H. \& Lodenius, M. 1987: Heavy metal levels in two biennial pine insects with sap-sucking and gall-forming lifestyles. - Environm. Poll. 48:13-23.

Horsfall, J.G. 1956: Principles of fungicidal action. -280 pp. Waltham, Mass.

Huttunen, S. 1978: The effects of air pollution on provenances of Scots pine and Norway spruce in northern Finland. - Silva Fenn. 12:1-16.

Huttunen, S. 1984: Interactions of disease and other stress factors with atmospheric pollution. - In: Treshow, M. (ed.), Air pollution and plant life, pp. 321-356. - 486 pp. Chichester.

Hynninen, V. 1986: Monitoring of airborne metal pollution with moss bags near an industrial source at Harjavalta, southwest Finland. - Ann. Bot. Fennici 23:83-90.

Hynninen, V. \& Lodenius, M. 1986: Mercury pollution near an industrial source in Southwest Finland. - Bull. Environm. Contam. Toxicol. 36:294-298.

Jordan, M.J. \& Lechevalier, M.P. 1975: Effects of zincsmelter emissions on forest soil microflora. - Can. J. Microbiol. 21:1855-1865.

Kowalski, T. 1981: Fungi infecting needles of Pinus sylvestris in Poland in relation to air pollution zone. - In: Millar, C.S. (ed.), Current research on conifer needle diseases, Proc. IUFRO W. P. on needle diseases, Sarajevo
1980: 93-98.

Kowalski, T. \& Budnik, M. 1976: Grzyby wystepujace w drzewostanach objetych szkodliwym oddzialywaniem emisji przemyslowych w Gornoslaskim i Krakowskim Okregu Przemyslowym I. Proba oceny wystepowania Lophodermium pinastri (Schrad.) Chev. na podstawie oznak etiologicznych no iglach sosnowych w sciole. - Acta Mycol. 12:131-139.

Kuokkanen, E. 1986: Harjavallan yhdyskuntailman mittaustulokset 1.6.1978-31.12.1985. - Ympäristö ja Terveys $5 / 1986: 286-291$.

Kurkela, T. 1979: Lophodermium seditiosum Minter et al. sienen esiintyminen männynkaristeen yhteydessä. (Summary: Association of Lophodermium seditiosum Minter et al. with a needle cast epidemic on Scots pine.) - Folia For. 393:1-11.

Laaksovirta, K. \& Silvola, J. 1975: Effect of air pollution by copper, sulphuric acid and fertilizer factories on plants at Harjavalta, W Finland. - Ann. Bot. Fennici 12:81-88.

Lechowicz, M.J. 1987: Resource allocation by plants under air pollution stress: Implications for plant-pest-pathogen interactions. - Bot. Rev. 53:281-300.

Miller, L.P. \& McCallan, S.E.A. 1957: Toxic action of metal ions to fungus spores. - J. Agric. Food Chem. $5: 116-122$.

Minter, D.W. 1981a: Lophodermium on pines. - Mycol. Papers 147:1-54.

Minter, D.W. 1981b: Lophodermium species on pines. In: Millar, C.S. (ed.), Current research of conifer needle diseases, Proc. IUFRO W. P. on needle diseases, Sarajevo 1980: 49-55.

Minter, D.W. \& Millar, C.S. 1984: Lophodermium pini-excelsae. - CMI Descriptions Pathogenic Fungi \& Bacteria 785, 1 p.

Minter, D.W., Staley, J.M. \& Millar, C.S. 1978: Four species of Lophodermium on Pinus sylvestris. Trans. Br. Mycol. Soc. 71:295-301.

Nash, T.H. III 1973: The effect of air pollution on other plants, particularly vascular plants. - In: Ferry, B.W., Baddeley, M.S. \& Hawksworth, D.L. (eds.), Air pollution and lichens, $389 \mathrm{pp}$. London.

Oszako, T. 1985: Grzyby jako bioindykatory zmian w ekosystemach lesnych pod wplywem przemyslowych zanieczyszczen powietrza. (Summary: Fungi as bioindicators of the effects of industrial air pollution on forest ecosystems.) - Sylwan 129(12): 33-42.

Rühling, Å, Bååth, E., Nordgren, A. \& Söderström, B. 1984: Fungi in metal-contaminated soil near the Gusum brass mill, Sweden. - Ambio 13:34-36.

Sippola, J. Erviö, R. 1986: Raskasmetallit maaperässä ja viljelyskasveissa Harjavallan tehtaiden ympäristössä. Ympäristö ja Terveys 5/1986: 270-275.

Smith, W.H. 1977: Influence of heavy metal leaf contaminants on the in vitro growth of urban tree phylloplanefungi. - Microbial Ecol. 3:231-239.

Winterhoff, W. \& Krieglsteiner, G.J. 1984: Gefährdete Pilze in Baden-Württenberg. Rote Liste der gefährdeten Grosspilze in Baden-Württenberg. - Beih. Veröff. Naturschutz Landschaftspflege Bad.-Württ. 40:1-120. 